\title{
Estudo das Trajetórias de Letramento em Curso de Educação a Distância: o texto, o papel e a tela do computador
}

Nádie Christina Ferreira Machado

Orientadora: Marie J ane Soares Carvalho

Coorientadora: Magda Bercht

Data da defesa: 14 de abril de 2009

O uso de tecnologias de comunicação e informação e o consequente crescimento de cursos de graduação a distância conduzem à necessidade de compreensão dos processos de letramento. Este estudo apresenta a análise de uma nova perspectiva de letramento - ou letramentos -, neste caso, as práticas de oralidade, leitura e escrita de alunas-professoras de um curso de Pedagogia na modalidade a distância. Entendemos este como um processo contínuo, observável na produção textual e analisado no contexto dialógico da produção acadêmica. Constatamos, pois, que as demandas reais promovem o desenvolvimento de diversas competências e habilidades, gerando mudanças significativas no estado ou na condição dos letramentos. As conquistas nos âmbitos da oralidade, escrita e leitura transcendem o espaço acadêmico, ao se materializarem, de modo qualificado, nas práticas profissionais e na vida pessoal. A metodologia adotada no estudo foi a netnografia, que privilegia a imersão do pesquisador na comunidade e permite analisar os significados das produções dos sujeitos em suporte digital. Trabalhamos com duas perspectivas: (1) geral, que considera os eventos e as práticas coletivas; e (2) particular, que se detém na análise das trajetórias singulares dos sujeitos. Os letramentos são analisados na produção acadêmica, a partir do estado ou da condição inicial de cada sujeito em foco, acompanhando-se as mudanças por um período de cinco semestres de curso. No âmbito geral, o estudo demonstra que as alunasprofessoras desenvolveram potencialidades em termos de autoria, edição e distribuição de textos no suporte digital. Em termos individuais, pode-se afirmar que o desenvolvimento de habilidades adquiridas na modalidade a distância foram incorporadas às ações acadêmicas e educativas por meio de novas metodologias de ensino-aprendizagem, em relação a que a tecnologia de informação e comunicação desempenha papel cada vez mais importante, alterando a performance de letramento dos envolvidos, não apenas nas práticas de suporte digital como também naquelas que envolvem as habilidades orais e o letramento alfabético.

Palavras-chave: Letramento. Letramento digital. Educação a distância. Oralidade. Leitura. Escrita. Papel. Tela do computador.

Referência: MACHADO, Nádie Christina Ferreira. Estudo das Trajetórias de Letramento em Curso de Educação a Distância: o texto, o papel e a tela do computador. Orientadora: Marie Jane Soares Carvalho. Coorientadora: Magda Bercht. 2009. Tese (doutorado) - Programa de Pós-Graduação em Informática na Educação, Centro de Estudos Interdisciplinares em Novas Tecnologias da Educação, Universidade Federal do Rio Grande do Sul, 2009, Porto Alegre. 